\title{
Manganese provides antioxidant protection for sperm cryopreservation that may offer new consideration for clinical fertility
}

\author{
Ranjna S. Cheema, * Amrit K. Bansal and Gurmail Singh Bilaspuri \\ Department of Animal Reproduction and Gynecology; Guru Angad Dev Veterinary and Animal Sciences University; Ludhiana, India
}

Abbreviations: EYC, egg yolk citrate; EYC-G, egg yolk citrate-glycerol; HOS, hypo-osmotic swelling; LPO, lipid peroxidation; MDA, malondialdehyde; ROS, reactive oxygen species; SOD, superoxide dismutase; TBA, thiobarbituric acid

Key words: cattle, lipid peroxidation, manganese, semen, oxidative stress

Reactive oxygen species (ROS) are generated by sperm metabolism. While, ROS are required for maturation, capacitation and acrosome reaction, they also modify many peroxidable cellular compounds. There is production of ROS during cryopreservation and frozen spermatozoa are highly sensitive to lipid peroxidation (LPO). Antioxidants exert a protective effect on the plasma membrane of frozen bovine sperm preserving both metabolic activity and cellular viability. Manganese $\left(\mathrm{Mn}^{++}\right)$is proved to be a chain breaking antioxidant in biological system. Therefore, we examined the role of $\left(\mathrm{Mn}^{++}\right)$during cryopreservation of cattle bull semen. Semen was divided into four parts and cryopreserved in egg-yolk-citrate extender + glycerol (EYCG), EYC-G + $100 \mu \mathrm{M}$ of $\mathrm{Mn}^{++}$, EYC-G + $150 \mu \mathrm{M}$ of $\mathrm{Mn}^{++}$ and EYC-G $+200 \mu \mathrm{M}$ of $\mathrm{Mn}^{++}$. After four hours of cooling and $24 \mathrm{hrs}$ of freezing, the spermatozoa were examined for percentage motility, Hypo-osmotic swelling (HOS), LPO and protein leakage. Addition of manganese to the semen during cryopreservation showed a protective effect and accounted for an increase in semen quality parameters [percentage motility, HOS percent and decrease in malondialdehyde (MDA) production and protein leakage]. The effect of manganese on motility and HOS was non-significant $(\mathrm{p}<0.05)$ in cooled spermatozoa but significant with $150 \mu \mathrm{M}$ of $\mathrm{Mn}^{++}$in frozen-thawed spermatozoa. MDA production and protein leakage decreased to a significant and maximum level $(\mathrm{p}<0.05)$ on addition of $200 \mu \mathrm{M}$ of manganese. The addition of manganese to EYC-G dilutor will improve the quality/fertility of semen, which will result in improvement of in vitro fertilization and artificial insemination success rate.

*Correspondence to: Ranjna S. Cheema; Department of Animal Reproduction; Gynecology and Obstetrics; Guru Angad Dev Veterinary and Animal Sciences University; Ludhiana-141004; Punjab, India; Tel.: +91.9464416085; Email: ranjna_cheema@hotmail.com

Submitted: 03/20/09; Revised: 04/21/09; Accepted: 04/21/09

Previously published online as an Oxidative Medicine and Cellular Longevity E-publication:

http://www.landesbioscience.com/journals/oximed/article/8804

\section{Introduction}

It is generally accepted that the consequences of sperm cryoinjury caused by the cryopreservation are impaired transport and poor survival in the female reproductive tract. ${ }^{1}$ The sperm plasma membrane is the primary site of damage induced by cryopreservation. $^{2-4}$ Both freezing and thawing cause tremendous alterations in cell water volume, which confer considerable mechanical stress on the cell membrane. ${ }^{2}$ Although a significant physiological role of ROS during normal sperm function has been reported, ${ }^{5,6}$ such as they facilitate fusogenicity of the spermatozoa, which enables them to bind to the zona pellucida, undergo the acrosome reaction through membrane lipid peroxidation and phospholipase-A activity, ${ }^{7}$ traverse through the zona pellucida and fuse with oocyte membrane, ${ }^{8}$ but when the balance between ROS production and detoxification by antioxidants is disrupted, an excess of ROS create oxidative stress. Unsaturated fatty acids, predominant in sperm membrane are susceptible to peroxidation? and leads to membrane damage, inhibition of respiration and leakage of intracellular enzymes. ${ }^{10}$ LPO increases after cryopreservation in bull semen. ${ }^{11}$

Improvement in sperm quality upon addition of antioxidants to semen indicates indirect evidences for the damaging effects of ROS in sperm function. The scavenging potential of the ejaculate is normally maintained by adequate levels of antioxidants, present in seminal plasma. Sperm oxidative damage is the result of an improper balance between ROS generation and scavenging activities. In domestic animals, defective and dead spermatozoa have been identified as a major source of ROS generation during cryopreservation. Radical scavenging activity of manganese related to the rapid quenching of peroxyl radicals has been demonstrated in the biological system viz, a typical antioxidative property of $\mathrm{Mn}^{++}$may protect substantial nigra compact neurons from iron induced oxidative stress; ${ }^{12}$ It could reduce the ferrous-ascorbatemediated lipid peroxidation in placental membranes; ${ }^{13}$ It induces an increase in the iron level, which provides direct evidence for Fe-mediated lipid peroxidation in the rat's brain that play an important role in the mechanism of $\mathrm{Mn}$ induced neurotoxicology; ${ }^{14}$ 
Mn-SOD transgene product protects frozen bone marrow cells/ irradiated at $24^{\circ} \mathrm{C} ;{ }^{15} \mathrm{Mn}$ mew-tetrakas porphyrin also results in significantly blunt nitration of renal proteins during renal ischemia/reperfusion by blocking oxidant production and inducing ATP-synthase-beta subunit and prevention of ATP depletion. ${ }^{16}$ Therefore, the present study evaluated the potential effect of $\mathrm{Mn}^{++}$ in a dose dependent manner against cryopreservation induced damage to cattle bull spermatozoa. Spermatozoa were monitored for post thaw survival, HOS test, LPO and protein leakage.

\section{Results}

Effect of $\mathrm{Mn}^{++}$on motility and HOS. Manganese added showed a protective effect and accounted for significantly higher values of motility and HOS-test response in cooled and frozen-thawed semen samples. A sperm motility declined to $63.3 \pm 6.8 \%$ and 45 $\pm 2.4 \%$ in the cooled and frozen-thawed semen samples, diluted in EYC-G without $\mathrm{Mn}^{++}$respectively. Whereas the percentage of motile spermatozoa declined to $67.5 \pm 2.0,45.0 \pm 2.4,66.6 \pm 5.9$, $66.6 \pm 3.0$ and $48.3 \pm 4.9,58.3 \pm 3.6,51.6 \pm 3.0$ in the cooled and frozen thawed semen sample, supplemented with $100 \mu \mathrm{M}$, $150 \mu \mathrm{M}, 200 \mu \mathrm{M}$ of $\mathrm{Mn}^{++}$respectively (Table 1, Fig. 1).

There was $16.7 \%$ and $35 \%$ loss of sperm motility in the semen samples cryopreserved in EYC-G without $\mathrm{Mn}^{++}$after cooling and freezing-thawing respectively. But the loss of motility decreased to only $12.5 \%, 13.4 \%, 13.4 \%$ and $31.7 \%, 21.7 \%, 28.4 \%$ on addition of $100 \mu \mathrm{M}, 150 \mu \mathrm{M}, 200 \mu \mathrm{M}$ of $\mathrm{Mn}^{++}$in the cooled and frozen-thawed semen samples respectively (Table 1 and Fig. 1). It indicates non-significant $(\mathrm{p}<0.05)$ effect of $\mathrm{Mn}^{++}$on percentage motility of cooled spermatozoa and a significant $(\mathrm{p}<0.05)$ effect on frozen-thawed spermatozoa, but $150 \mu \mathrm{M}$ concentration of $\mathrm{Mn}^{++}$showed a maximum protective effect.

The percentage of HOS +ve spermatozoa was $55.7 \pm 2.8 \%$ in the freshly diluted semen, which declined to $46.7 \pm 2.8 \%$ and $19.17 \pm 4.4 \%$ in the cooled and frozen-thawed semen samples, diluted in EYC-G without $\mathrm{Mn}^{++}$respectively. The percentage of $\mathrm{HOS}$ +ve spermatozoa further declined to $45.1 \pm 5.1 \%, 43.0 \pm$ $6.4 \%, 44.2 \pm 3.1 \%$ in the cooled semen samples and $23.19 \pm$ $3.9 \%, 30.1 \pm 6.9 \%, 24.25 \pm 5.2 \%$ in the frozen-thawed semen samples, supplemented with $100 \mu \mathrm{M}, 150 \mu \mathrm{M}, 200 \mu \mathrm{M}$ of $\mathrm{Mn}^{++}$ respectively (Table 2 and Fig. 2).

The percentage of HOS +ve spermatozoa declined to $8.97 \%$ in cooled semen samples, diluted in EYC-G without manganese. But this decline was increased to $10.60 \%, 12.70 \%, 11.50 \%$ in cooled semen samples supplemented with 100,150 and $200 \mu \mathrm{M}$ of $\mathrm{Mn}^{++}$. A percentage of $27.56 \%$ in HOS was observed in semen samples, cryopreserved in EYC-G without $\mathrm{Mn}^{++}$, whereas a decrease $21.91 \%, 12.84 \%$ \& $19.95 \%$ in HOS +ve spermatozoa was observed in frozen thawed semen samples, supplemented with 100, $150 \& 250 \mu \mathrm{M}$ of $\mathrm{Mn}^{++}$(Table 2 and Fig. 2).

The results indicate non-significant $(\mathrm{p}<0.05)$ effect of $\mathrm{Mn}^{++}$ on sperm membrane integrity during the cooling process and significant $(\mathrm{p}<0.05)$ effect during the freezing process, but to a maximum level on addition of $150 \mu \mathrm{M}$ of $\mathrm{Mn}^{++}$.

Effect of $\mathrm{Mn}^{++}$on lipid peroxidation and protein-leakage. Only $45.0 \pm 3.3 \mu$ moles $/ 10^{9}$ cells of MDA were produced in the
Table 1 Manganese increases sperm motility during cryopreservation of cattle bull semen

\begin{tabular}{lcccc}
$\begin{array}{l}\text { Concentration } \\
\text { of } \mathrm{Mn}^{++}(\mu \mathrm{M})\end{array}$ & \multicolumn{4}{c}{ Motility (Mean \pm S.E.) } \\
& Pre-Freezing & $\begin{array}{c}\text { Decrease in } \\
\text { motility (\%) }\end{array}$ & Post-Thaw & $\begin{array}{c}\text { Decrease in } \\
\text { motility (\%) }\end{array}$ \\
Control & $80.0 \pm 0.0^{\mathrm{a}}$ & - & - & - \\
0 & $63.3 \pm 6.8^{\mathrm{bc}}$ & 16.7 & $45.0 \pm 2.4^{\mathrm{d}}$ & 35 \\
100 & $67.5 \pm 2.0^{\mathrm{c}}$ & 12.5 & $48.3 \pm 4.9^{\mathrm{d}}$ & 31.7 \\
150 & $66.6 \pm 5.9^{\mathrm{c}}$ & 13.4 & $58.3 \pm 3.6^{\mathrm{b}}$ & 21.7 \\
200 & $66.6 \pm 3.0^{\mathrm{c}}$ & 13.4 & $51.6 \pm 3.0^{\mathrm{d}}$ & 28.4
\end{tabular}

Superscripts $(a, b, c$ and $d)$ indicate the difference at $5 \%$ level of significance within the columns. The table depicts non-significant protective effect of $\mathrm{Mn}^{++}$on percentage motility of cooled spermatozoa and significant and significant $(p \leq 0.05)$ effect on that of frozen thawed spermatozoa. $150 \mu \mathrm{M}$ concentration of Mn showed a maximum protective effect.

freshly diluted semen, which increased to $73.3 \pm 1.6$ and 122.5 $\pm 6.9 \mu$ moles $/ 10^{9}$ cells in the cooled semen samples, diluted in EYC-G without $\mathrm{Mn}^{++}$. MDA production was reduced to $66.96 \pm$ $2.0,63.43 \pm 4.2,56.26 \pm 1.6 \mu$ moles $/ 10^{9}$ cells in the cooled semen samples and to $101.8 \pm 1.4,96.8 \pm 7.7,75.3 \pm 2.2$ in the frozenthawed semen samples, supplemented with 100,150 and $200 \mu \mathrm{M}$ of $\mathrm{Mn}^{++}$respectively (Table 3 and Fig. 3).

It shows a significant increase in MDA production in the cooled as well as frozen-thawed spermatozoa irrespective of the addition of $\mathrm{Mn}^{++}$to EYC-G (Table 3). The results indicate an increase of $38.82 \%$ and $40.16 \%$ in the cooled and frozen thawed spermatozoa, diluted in EYC-G without $\mathrm{Mn}^{++}$. Comparatively the percentage of MDA production decreased to $30.82 \%, 29.08 \%$ and $19.96 \%$ in the cooled spermatozoa and to $36.05 \%, 34.47 \%$ and $25.18 \%$ in frozen-thawed spermatozoa, supplemented with $100 \mu \mathrm{M}, 150 \mu \mathrm{M}$ and $200 \mu \mathrm{M}$ of $\mathrm{Mn}^{++}$respectively. However, progressive decline in MDA production with an increase in concentration of $\mathrm{Mn}^{++}$was observed. Anti-oxidant effect of $\mathrm{Mn}^{++}$was significant $(\mathrm{p}<0.05)$ in cooled as well as frozen-thawed semen samples but to a maximum level on addition of $200 \mu \mathrm{M}$ of $\mathrm{Mn}^{++}$.

The total protein content of freshly diluted washed spermatozoa was $18.72 \mathrm{mg} / 10^{9}$ spermatozoa. The protein content of cooled spermatozoa declined to $15.53 \pm 1.8,16.35 \pm 1.4,16.73$ \pm 8.4 and $16.84 \pm 8.0 \mathrm{mg} / 10^{9}$ cells, diluted in EYC-G, EYC-G $+100 \mu \mathrm{M}, \mathrm{EYC}-\mathrm{G}+150 \mu \mathrm{M}$ and EYC-G + $200 \mu \mathrm{M}$ of $\mathrm{Mn}^{++}$ respectively. The protein content of frozen-thawed spermatozoa further declined to $8.65 \pm 1.0,10.71 \pm 8.5,9.68 \pm 5.3$ and 12.50 $\pm 6.2 \mathrm{mg} / 10^{9}$ cells, cryopreserved in EYC-G, EYC-G + $100 \mu \mathrm{M}$, $\mathrm{EYC}-\mathrm{G}+150 \mu \mathrm{M}$ and EYC-G $+200 \mu \mathrm{M}$ of $\mathrm{Mn}^{++}$respectively (Table 4, Fig. 4).

There was $17.04 \%$ and $44.30 \%$ leakage of total sperm proteins in the cooled and frozen-thawed semen samples, diluted in EYC-G without $\mathrm{Mn}^{++}$(Fig. 5, Table 4). The leakage of total sperm proteins was reduced to $12.66 \%, 10.63 \%$ and $10.04 \%$ and $34.49 \%, 42.14 \%$ and $25.77 \%$ in cooled and frozen thawed semen, supplemented with $100 \mu \mathrm{M}, 150 \mu \mathrm{M}$ and $200 \mu \mathrm{M}$ of $\mathrm{Mn}^{++}$respectively. The results indicate that the 


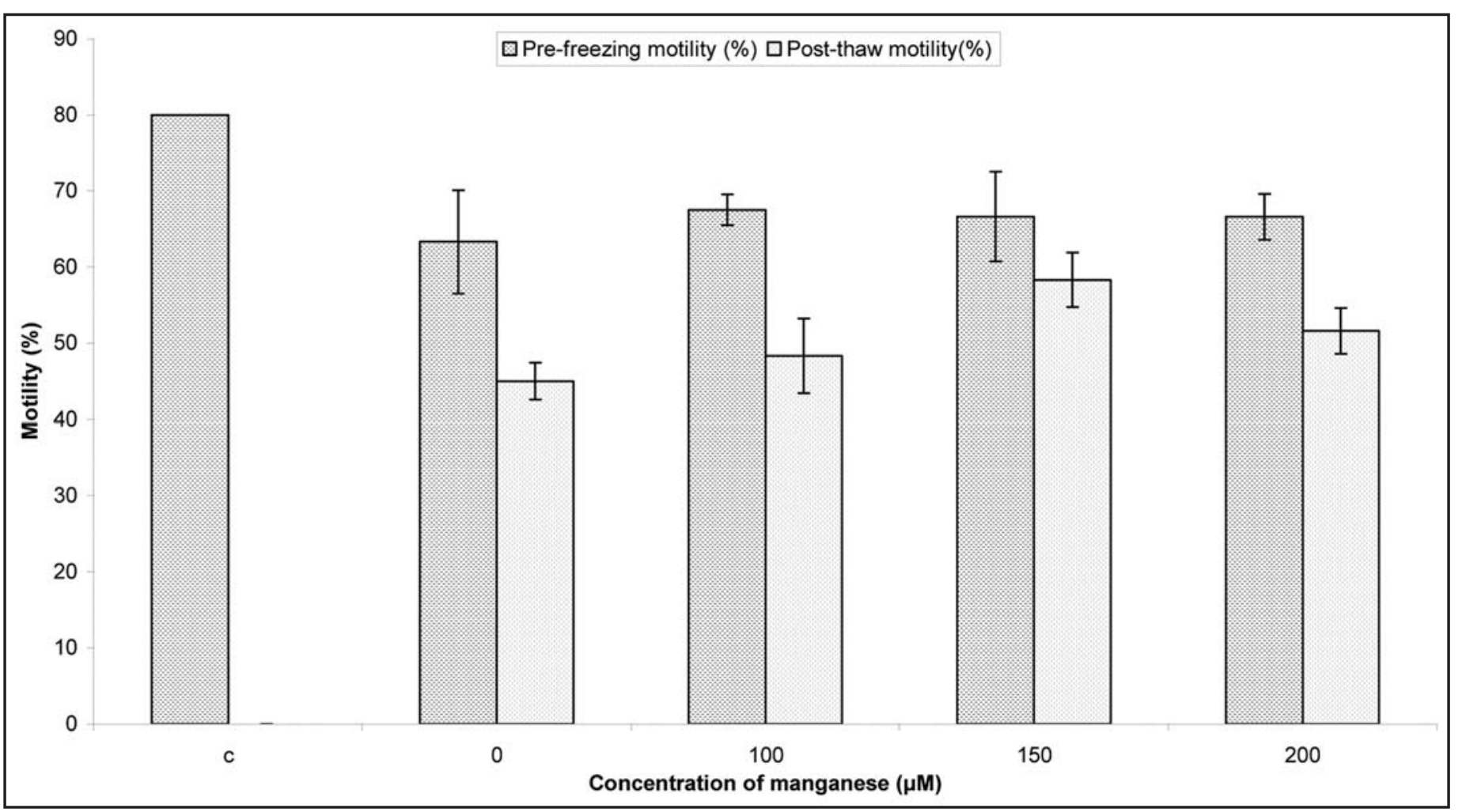

Figure 1. Manganese increases sperm motility $(\%$, Mean \pm SE) during cryopreservation of cattle bull semen. The figure depicts non-significant protective effect of $\mathrm{Mn}^{++}$on percentage motility of cooled spermatozoa and significant and significant $(p \leq 0.05)$ effect on that of frozen-thawed spermatozoa. $150 \mu \mathrm{M}$ concentration of $\mathrm{Mn}^{++}$showed a maximum protective effect.

\section{Table 2 Manganese increases HOS percentage (mean \pm S.E) during cryopreservation of cattle bull spermatozoa}

\begin{tabular}{lcccc}
\hline $\begin{array}{c}\text { Conc of } \\
\mathrm{Mn}^{++}(\mu \mathrm{M})\end{array}$ & $\begin{array}{c}\text { Spermatozoa cooled } \\
\text { at } \mathbf{4}^{\circ} \mathbf{C} \\
\text { Difference in } \\
\text { HOS (\%) } \\
\text { between control } \\
\text { \& cooled } \\
\text { spermatozoa }\end{array}$ & $\begin{array}{c}\text { Frozen-thawed } \\
\text { spermatozoa } \\
\text { HOS (\%) }\end{array}$ & $\begin{array}{c}\text { Difference in } \\
\text { HOS (\%) } \\
\text { between cooled } \\
\text { and frozen-thawed } \\
\text { spermatozoa }\end{array}$ \\
Control & $55.7 \pm 2.8^{\mathrm{a}}$ & - & - & - \\
0 & $46.7 \pm 2.8^{\mathrm{b}}$ & 8.97 & $19.17 \pm 4.4^{\mathrm{c}}$ & 27.56 \\
100 & $45.1 \pm 5.1^{\mathrm{b}}$ & 10.60 & $23.19 \pm 3.9^{\mathrm{c}}$ & 21.91 \\
150 & $43.0 \pm 6.4^{\mathrm{b}}$ & 12.70 & $30.1 \pm 6.9^{\mathrm{d}}$ & 12.84 \\
200 & $44.2 \pm 3.1^{\mathrm{b}}$ & 11.50 & $24.25 \pm 5.2^{\mathrm{c}}$ & 19.95
\end{tabular}

Superscripts $(a, b, c$ and $d)$ indicate the difference at $5 \%$ level of significance within the columns. This table depicts non-significant $(p \geq 0.05)$ effect of $\mathrm{Mn}^{++}$on sperm membrane integrity in cooled semen samples and significant $(p \leq 0.05)$ effect in frozen thawed semen samples, but to a maximum level on addition of $150 \mu \mathrm{M} \mathrm{Mn}^{++}$.

addition of $\mathrm{Mn}^{++}$to EYC-G could control the leakage of sperm membrane proteins to a significant level $(\mathrm{p}<0.05)$ both in cooled and frozen-thawed semen, but to a maximum level on addition of $200 \mu \mathrm{M}$ of $\mathrm{Mn}^{++}$.

\section{Discussion}

Much of cryopreservation sperm damage depends on the structural stability of the plasma membrane. ${ }^{17}$ The structural re-organization of sperm head plasma membrane after cryopreservation appears to disrupt the ability of the sperm to interact normally with cells of the female genital tract. Cryopreservation in the presence of cryoprotectants (typically glycerol) is considered to be a more moderate treatment than cold shock. Since impaired sperm membrane function due to cryopreservation inevitably affects capacitation, acrosome reaction, penetration into zona, fusion and penetration into the oolema and so diminishes successful fertilization in vivo. That is why when equal number of motile spermatozoa are inseminated, the fertility of fresh semen is superior to that of frozen semen. Manganese is an element of great importance in the life cycle of plants/animals and it plays an essential role as an activator of various enzymatic systems. Antioxidant effect of $\mathrm{Mn}^{++}$or its protective effect against LPO has been studied in various biological systems. ${ }^{12-14,18}$ In various organisms, high intracellular manganese provide protection against oxidative damage through unknown pathways and recently it has been found that manganese for oxidative protection is provided by the Nramp transporters. ${ }^{19}$ The potential role of manganese in evaluation of infertile males has also been reported..$^{20}$ Elbetieha et al. ${ }^{21}$ also postulated that ingestion of high dose of manganese chloride by 


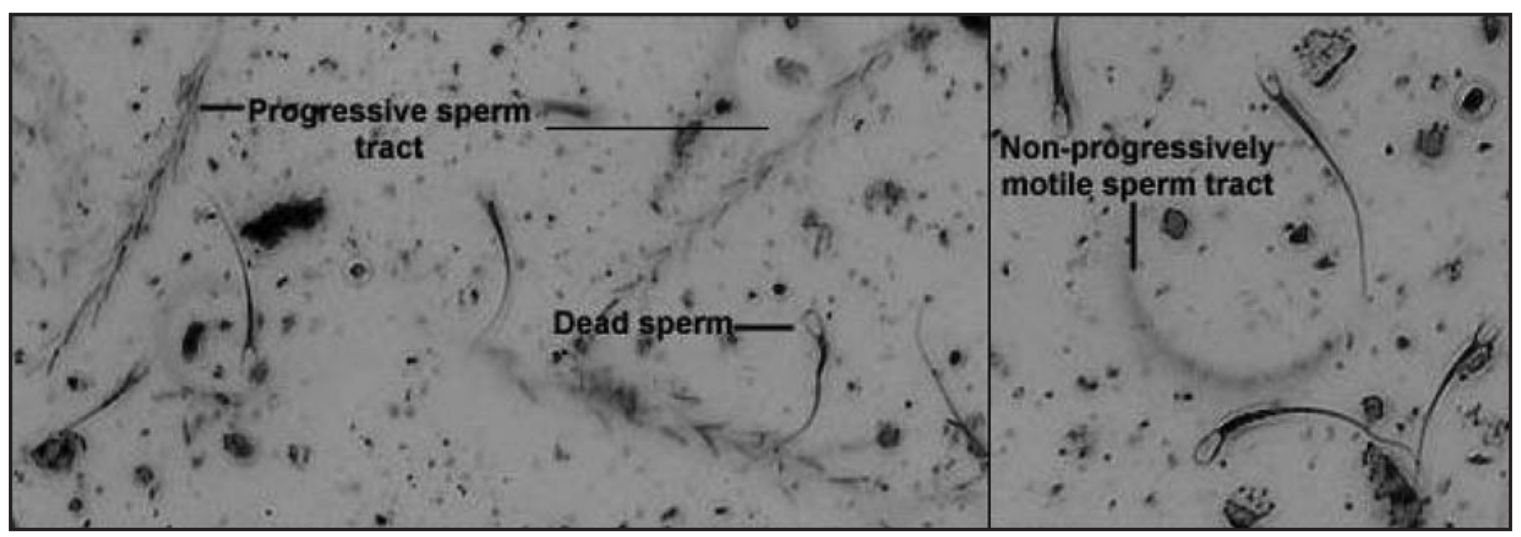

Figure 2. Cattle bull spermatozoa showing progressive and non-progressive motility.

male and female mice causes some adverse effects on fertility and reproduction. $\mathrm{Mn}^{++}$has a peroxyl radical scavenging activity, which seems to be related to the rapid quenching of peroxyl radicals according to the reaction $\mathrm{R}-\mathrm{OO}+\mathrm{Mn}^{++}+\mathrm{H}(+) \rightarrow$ $\mathrm{ROOH}^{+}+\mathrm{Mn}^{22}$

Effect of $\mathrm{Mn}^{++}$on motility and HOS. A subpopulation of sperm survives and maintains fertilizing capacity not withstanding an overall reduction in the percentage of motile and viable cells. However, computer assisted motility of bovine sperm, immediately after thawing is not correlated with fertility. ${ }^{23}$ Similarly Lapointe et al. ${ }^{24}$ suggested the beneficial effect of $0.1 \mathrm{mM} \mathrm{MnCl}_{2}$ for the maintainace of sperm motility without detrimental effects on mucus penetration and fertilizing ability and hypothesized that $\mathrm{Mn}^{++}$would have an effect on sperm cyclase activity that lead to increased $\mathrm{Ca}^{++}$concentration and motility. However, despite preservation of adequate motility, cryopreserved human sperm exhibit significant membrane damage as indicated by subnormal hypo-osmotic swelling tests. ${ }^{25}$ During the present studies, although the post thaw motility ranged from $45.0 \%$ to $51.6 \%$ in all the experiments but the percentage of HOS +ve spermatozoa ranged only from $19.95 \%$ to $27.56 \%$. It shows that even motile spermatozoa have damaged membrane. About 36-47\% reduction in normal morphology i.e., motility, viability, mitochondrial function has been observed in frozenthawed human spermatozoa. ${ }^{26}$ It has also been reported that the release of oxidase from dead sperms in EYC reduces the motility and viability of remaining living bull spermatozoa. ${ }^{27}$ Therefore, the addition of $\mathrm{Mn}^{++}$to EYC-G resulted in significant improvement in the post-thaw motility and HOS of frozen cattle bull spermatozoa in a dose dependent manner, which was maximum on addition of $150 \mu \mathrm{M}$ of $\mathrm{Mn}^{++}$. Similarly the addition of $\mathrm{Mn}^{++}$to human washed spermatozoa resulted in stimulation of progressive motility in a time and dose dependent manner. ${ }^{28}$ The positive effects of antioxidants vitamin $\mathrm{E}$ and $\mathrm{Mn}^{++}$have been studied on buffalo and cattle bull spermatozoa incubated with lipid peroxidation catalysts. ${ }^{29,30}$

Effect of $\mathrm{Mn}^{++}$on lipid peroxidation and protein-leakage. Although a significant negative correlation between the ROS and IVF fertilization rate has been found, ${ }^{31}$ controlled quantities of
Table 3 Manganese decreases the malondialdehyde production (mean $\pm \mathrm{SE}$ ) during cryopreservation of cattle bull spermatozoa

\begin{tabular}{|c|c|c|c|c|}
\hline \multirow{2}{*}{$\begin{array}{l}\text { Conc of } \\
\mathrm{Mn}^{++} \\
(\mu \mathrm{M})\end{array}$} & \multicolumn{2}{|c|}{$\begin{array}{l}\text { Spermatozoa cooled } \\
\text { at } 4^{\circ} \mathrm{C}\end{array}$} & \multicolumn{2}{|c|}{$\begin{array}{l}\text { Frozen-thawed } \\
\text { spermatozoa }\end{array}$} \\
\hline & $\begin{array}{c}\text { MDA } \\
\text { produced } \\
\mu \mathrm{M} / 10^{9} \\
\text { cells }\end{array}$ & $\begin{array}{l}\text { Difference in } \\
\text { MDA } \\
\text { production } \\
\text { (freshly diluted } \\
\text { \& cooled } \\
\text { sperms) }\end{array}$ & $\begin{array}{c}\text { MDA } \\
\text { produced } \\
\mu \mathrm{M} / 10^{9} \\
\text { cells }\end{array}$ & $\begin{array}{l}\text { Difference in } \\
\text { MDA } \\
\text { production } \\
\text { (cooled \& } \\
\text { frozen-thawed } \\
\text { sperms) }\end{array}$ \\
\hline Control & $45.03 \pm 3.3^{a}$ & - & - & - \\
\hline 0 & $73.33 \pm 1.6^{b}$ & 38.55 & $122.5 \pm 6.9^{e}$ & 40.16 \\
\hline 100 & $66.96 \pm 2.0^{c}$ & 30.82 & $101.8 \pm 1.4^{f}$ & 36.05 \\
\hline 150 & $63.43 \pm 4.2^{\mathrm{c}}$ & 29.08 & $96.8 \pm 7.79$ & 34.47 \\
\hline 200 & $56.26 \pm 1.6^{d}$ & 19.96 & $75.2 \pm 2.2^{h}$ & 25.18 \\
\hline
\end{tabular}

Superscripts $(a, b, c, d, e, f, g$ and $h)$ indicate the difference at $5 \%$ level of significance within the columns. This table depicts significant antioxidant effect of $\mathrm{Mn}^{++}$in cooled as well as frozen thawed

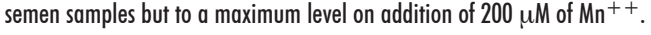

ROS have shown to be essential for the development of capacitation and hyper activation, ${ }^{32}$ two physiological processes of the sperm that are necessary to ensure fertilization. The maintenance of a suitable ROS level is therefore essential for adequate sperm functionality.

When the balance between ROS production and detoxification by antioxidants is disrupted, an excess of ROS such as $\mathrm{H}_{2} \mathrm{O}_{2}$, $\mathrm{SO}$ etc., creates oxidative stress and results in membrane damage. The activation of an aromatic amino acid oxidase following the death of ram and bull spermatozoa has been identified as major source of ROS production in the semen of these animals. ${ }^{33}$ It has been reported that LPO in bull spermatozoa increases after cryopreservation. ${ }^{11}$ The cryopreservation of cattle bull spermatozoa also resulted in an increase in LPO in terms of MDA production irrespective of the addition of $\mathrm{Mn}^{++}$. Frozen-thawed bull spermatozoa are more easily per oxidized than freshly ejaculated spermatozoa. ${ }^{34}$ The supplementation of $\mathrm{Mn}^{++}$could reduce the level of MDA 


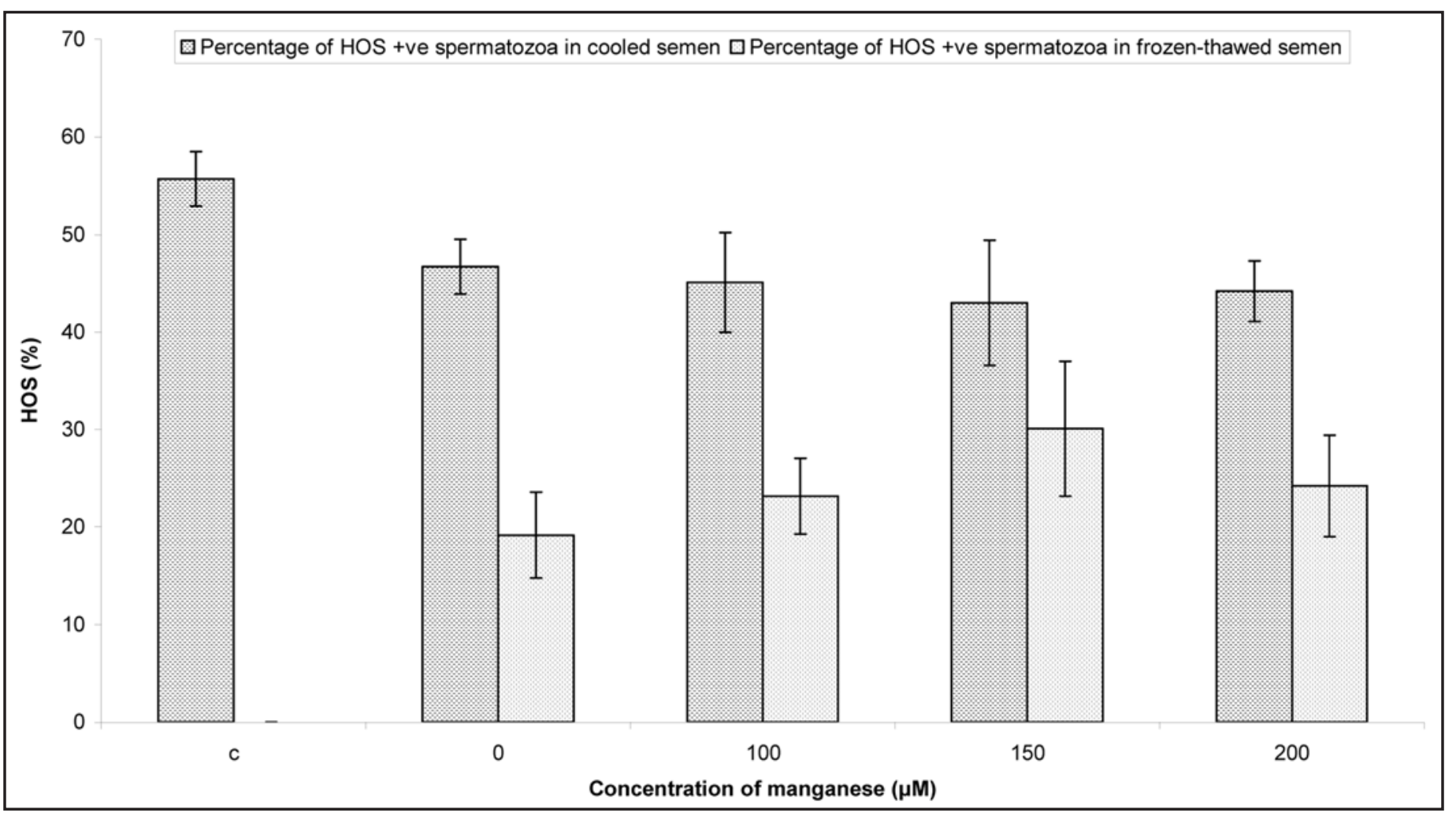

Figure 3. Manganese increases HOS percentage (Mean \pm SE) during cryopreservation of cattle bull spermatozoa. The figure depicts non-significant $(p \geq 0.05)$ effect of $\mathrm{Mn}^{++}$on sperm membrane integrity in cooled semen samples and significant $(p \leq 0.05)$ effect in frozen-thawed semen samples, but to a maximum level on addition of $150 \mu \mathrm{M}$ of $\mathrm{Mn}^{++}$.

\section{Table 4 Manganese decreases the leakage of total protein (mean $\pm \mathrm{SE}$ ) during cryopreservation of cattle bull spermatozoa}

\begin{tabular}{|c|c|c|c|c|}
\hline \multirow{2}{*}{$\begin{array}{l}\text { Conc of } \\
\mathrm{Mn}^{++} \\
(\mu \mathrm{M})\end{array}$} & \multicolumn{2}{|c|}{$\begin{array}{l}\text { Spermatozoa cooled } \\
\text { at } 4^{\circ} \mathrm{C}\end{array}$} & \multicolumn{2}{|c|}{$\begin{array}{l}\text { Frozen-thawed } \\
\text { spermatozoa }\end{array}$} \\
\hline & $\begin{array}{c}\text { Protein } \\
\text { leakage } \\
\mu \mathrm{M} / 10^{9} \\
\text { cells }\end{array}$ & $\begin{array}{l}\text { Increase in } \\
\text { protein } \\
\text { leakage } \\
\text { as compared } \\
\text { to control }\end{array}$ & $\begin{array}{c}\text { Protein } \\
\text { leakage } \\
\mu \mathrm{M} / 10^{9} \\
\text { cells }\end{array}$ & $\begin{array}{l}\text { Increase in } \\
\text { protein } \\
\text { leakage } \\
\text { as compared } \\
\text { to cooling }\end{array}$ \\
\hline Control & $18.72 \pm 3.6^{a}$ & - & - & - \\
\hline 0 & $15.53 \pm 1.8^{b}$ & 17.04 & $8.65 \pm 1.0^{c}$ & 44.30 \\
\hline 100 & $16.35 \pm 1.4^{b}$ & 12.66 & $10.71 \pm 5.5^{\mathrm{cd}}$ & 34.49 \\
\hline 150 & $16.73 \pm 5.4^{b}$ & 10.63 & $9.68 \pm 2.3^{c}$ & 42.14 \\
\hline 200 & $16.84 \pm 5.0^{b}$ & 10.04 & $12.50 \pm 4.2^{d}$ & 25.17 \\
\hline
\end{tabular}

Superscripts ( $a, b, c, d, e, f, g$ and $h$ ) indicate the difference at $5 \%$ level of significance within the columns. This table depicts that the addition of $\mathrm{Mn}^{++}$to EYC $-\mathrm{G}$ could reduce the leakage of total sperm proteins to a significant level both in cooled and frozen-thawed semen samples, which was maximum on addition of $200 \mu \mathrm{M}$ of $\mathrm{Mn}^{++}$.

production significantly in spermatozoa cooled at $4^{\circ} \mathrm{C}$ and frozenthawed spematozoa, but to a maximum level on addition of $200 \mu \mathrm{M}$ of $\mathrm{Mn}^{++}$. Inclusion of natural oxidants ( $\alpha$-tocopherol and ascorbate) had a protective effect on metabolic activity and cellular viability of cryopreserved bovine sperm. ${ }^{35,36}$ Similarly $\mathrm{Mn}^{++}$as an antioxidant showed a protective effect on cattle bull spermatozoa during cryopreservation.

The presence of antioxidant enzymes, SOD, glutathione peroxidase (GPx) and catalase in human; ${ }^{37}$ bull ${ }^{38}$ and ram $^{39,40}$ semen and the effect of semen dilution results in reducing their protective capacity. Marti et al. ${ }^{41}$ indicated a $65 \%$ decrease in SOD activity of ram spermatozoa after freezing-thawing and addition of seminal plasma proteins with oleic-linoleic acid \& vitamin $\mathrm{E}$ accounted for an increase in enzyme activity levels. In our study, sperm membrane damage due to oxidative stress during cryopreservation of cattle bull spermatozoa also resulted in protein leakage irrespective of the addition of $\mathrm{Mn}^{++}$. However, the addition of $\mathrm{Mn}^{++}$could prevent the leakage of proteins to a significant level in a dose dependent manner and the effect was maximum with $200 \mu \mathrm{M}$ of $\mathrm{Mn}^{++}$. Bilodeau et al. ${ }^{40}$ also observed a reduction in glutathione levels of bull spermatozoa during cryopreservation. Literature indicate that the enzyme system comprising SOD, glutathione peroxidase/reductase and catalase function as a defense against lipid peroxidation in mammalian sperm and defect of these enzyme activities could produce a loss to cell function. It can be further postulated from our results that supplementation of $\mathrm{Mn}^{++}$as an antioxidant to EYC-G during cryopreservation may maintain the enzyme system by its scavenging activity for free radicals or by reducing the oxidative stress and could reduce the effect of cryoinjury to cattle bull spermatozoa. 


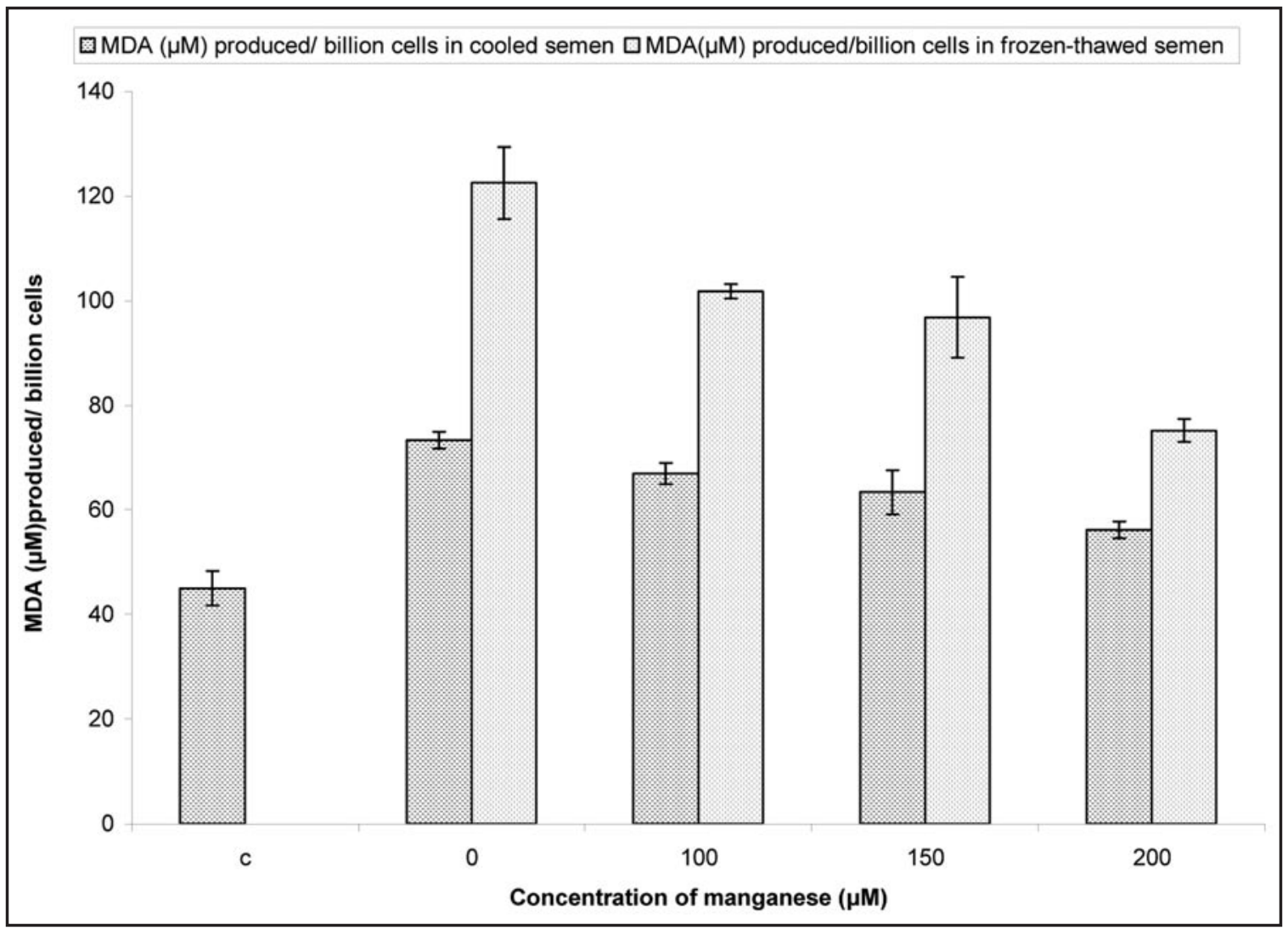

Figure 4. Manganese decreases the malondialdehyde (MDA) production (Mean $\pm \mathrm{SE}$ ) during cryopreservation of cattle bull spermatozoa. The figure depicts significant antioxidant effect of $\mathrm{Mn}^{++}$in cooled as well as frozen thawed semen samples but to a maximum level on additon of $200 \mu \mathrm{M}$ of $\mathrm{Mn}^{++}$.

It can be concluded that $200 \mu \mathrm{M}$ concentration of $\mathrm{Mn}^{++}$is an optimum dose, which can be added to EYC-G during cryopreservation of cattle bull spermatozoa to reduce the oxidative stress/ improve the quality of semen.

\section{Materials and Methods}

Procurement and evaluation of semen. Freshly ejaculated semen was collected with the help of artificial vagina, immediately transported to the lab and evaluated for its mass activity. A drop of semen was placed on a clean glass slide and observed under microscope $(10 \mathrm{x} 10 \mathrm{X})$ for waves, swirls and eddies. Grading was done on the basis of observations; Immotile/dead sperm (0), no waves but sperm movement $(+)$, slow wave formation $(++)$, relatively more wave formation with swirls $(+++)$, waves with swirls and eddies $(++++)$. The semen with only ++++ mass activity was used for freezing.

Experiment design. Three separate experiments were performed to evaluate the effect of adding different concentrations of $\mathrm{Mn}^{++}$to EYC-G on the post thaw sperm survival performance (pre-freezing motility, post thaw motility, HOS-test, LPO, protein leakage) as follows:-

Experiment 1. Addition of $100 \mu \mathrm{M}$ of $\mathrm{MnCl}_{2}$.

Experiment 2. Addition of $150 \mu \mathrm{M}$ of $\mathrm{MnCl}_{2}$.

Experiment 3. Addition of $200 \mu \mathrm{M}$ of $\mathrm{MnCl}_{2}$.

In all experiments treatments were compared to a sample without $\mathrm{Mn}^{++}$and to a control (freshly diluted semen).
Cryo-preservation of semen. Immediately EYC-G in the ratio of $1: 1$ was added to the semen and kept at $37^{\circ} \mathrm{C}$ for $5-10$ minutes. Semen with $80 \%$ initial motility was further diluted to $1: 8$ at a sperm concentration of about $100 \times 10^{6}$ cells $/ \mathrm{ml}$. Diluted semen samples of experiments $1-3$ and without $\mathrm{Mn}^{++}$were kept at $4^{\circ} \mathrm{C}$ in a cold handling cabinet for four hours. After checking the prefreezing motility, half of the semen was taken out to study various sperm functions. Second part of each experiment was cryopreserved using the straw freezing procedure. After 24 hours, semen was processed for post thaw motility and various sperm functions.

Sperm concentration. Sperm concentration was estimated spectrophotometrically by taking absorbance at $545 \mathrm{~nm}$, a standard curve for which was prepared (Sperm concentration, calculated with haemocytometer versus absorbance at $545 \mathrm{~nm}$.)

Percentage motility. Motility of pre-cooled and frozen-thawed semen was observed microscopically using CCTV. A total of 200 motile and non-motile sperms were observed on the monitor and percent of motile spermatozoa was calculated.

HOS-test. ${ }^{41}$ HOS-test indicates the membrane integrity of the spermatozoa and damage is caused to the sperm membrane during cryopreservation. Therefore, HOS-test was performed to find out the protective effect of $\mathrm{Mn}^{++}$on sperm damage. Briefly, $0.2 \mathrm{ml}$ of semen was incubated with $1.0 \mathrm{ml}$ of $100 \mu \mathrm{M}$ of HOS solution and $0.85 \%$ saline separately for 30 minutes. After 30 minutes spermatozoa with swollen and coiled tails were observed under microscope 


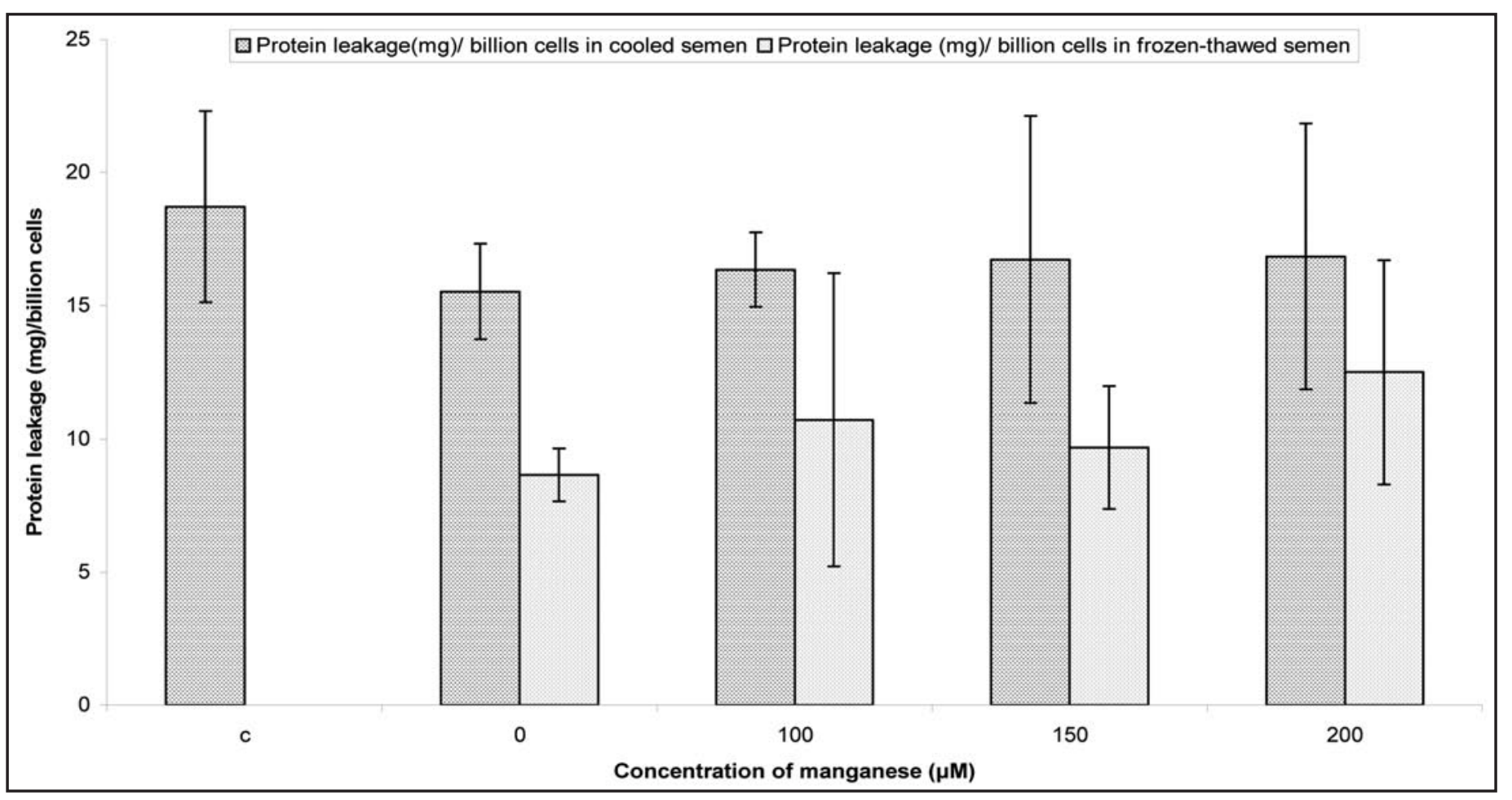

Figure 5. Manganese decreases the leakage of total protein (Mean $\pm \mathrm{SE}$ ) during cryopreservation of cattle bull spermatozoa.

at $10 \mathrm{x} 40 \mathrm{X}$. A total of 200 coiled/uncoiled sperms were counted and percent coiled spermatozoa were calculated. Percent of HOS positive spermatozoa was calculated by subtracting number of coiled sperms in normal saline from that in HOS solution.

Membrane lipid peroxidation. Oxidative stress is induced during cryopreservation of semen and as a result ROS are produced. Therefore, LPO was measured to find out an antioxidant effect of $\mathrm{Mn}^{++}$on oxidative stress. Membrane LPO was estimated by the end point generation of MDA determined by the TBA test. ${ }^{42}$ Briefly, extended spermatozoa [(40-70) $\times 10^{6}$ cells] in $0.5 \mathrm{ml}$ of cold $10 \%$ (wt/vol) chilled trichloroacetic acid to proliferate proteins. The precipitate was pelleted by centrifugation (6,000 rpm for 10 minutes) and $1 \mathrm{ml}$ of $0.375 \%$ (wt/vol) TBA was added to the supernatant and kept in a boiling water bath at $100^{\circ} \mathrm{C}$ for 10 minutes. After cooling, the absorbance was read at $532 \mathrm{~nm}$ (UV-VIS spectrophotometer, systronics, India). MDA production was calculated by the formula:

[O.D. at $532 \mathrm{~nm} \times$ Volume of assay mixture]/[Molar extinction coefficient $\mathrm{x}$ Volume of sample]

$\left(1.56 \times 10^{5} \mathrm{M}^{-1} \mathrm{C}^{-1}\right)$

Total proteins. There is leakage of sperm membrane enzymes and total proteins during cryopreservation. Therefore, total sperm protein was measured to find out the protective effect of $\mathrm{Mn}^{++}$on protein leakage. It was estimated by the standard method ${ }^{43}$ using $4-7 \times 10^{6}$ sperms $/ 0.05 \mathrm{ml}$. Bovine serum albumin was run as a standard.

Increase in MDA production and protein leakage due to cooling and freezing-thawing of spermatozoa was calculated by subtracting the values of control from that of cooled and of cooled samples from that of frozen-thawed ones respectively.
Statistical analysis. The data were analyzed by using computerized soft ware programmed for analysis of RBD (Randomized block design).

\section{Acknowledgements}

The authors are thankful to the semen freezing lab, Department of Animal Breeding and Genetics and GADVASU for providing the semen samples.

\section{References}

1. Salmon S, Maxwell WMC. Frozen storage of ram semen II. Cause of low fertility after cervical insemination and methods of improvement. Anim Reprod Sci 1995; 38:1-36.

2. Hammerstedt RH, Graham JK, Nolan JP. Cryopreservation of mammalian sperm: what we ask them to survive. J Androl 1990; 11:73-88.

3. Parks JE, Graham JK. Effects of cryopreservation procedures on sperm membrane. Theriogenol 1999; 51:461-72.

4. Watson PF. Recent developments and concepts in cryopreservation of spermatozoa and assessment of their post-thawing functions. Reprod Fertil Dev 1995; 7:871-91.

5. Kodama H, Kuribayashi Y, Gagnon C. Effect of sperm lipid peroxidation on fertilization. J Androl 1996; 17:151-7.

6. de Lamirande E, Jiang H, Zini A, Kodama H, Gagnon C. Reactive oxygen species and sperm physiology. Rev Reprod 1997; 2:48-54.

7. Awda BJ, Machenzie-Bell M, Buhr MM. Reactive oxygen species and boar sperm function. Biol Reprod 2009; In press.

8. Michael AJ, Alexopoulos C, Pontiki EA, Hadjipppavlou-Lintina DJ, Saratsis P, Ververdis $\mathrm{HN}$, et al. Effect of antioxidant supplementation in semen extenders on semen quality and reactive oxygen species of chilled canine spermatozoa. Anim Reprod Sci 2009; 112:119-35.

9. Halliwell B, Gutteridge J. Lipid peroxidation, oxygen radicals, cell damage and antioxidant therapy. Lancet 1984; 1:1396-8.

10. White IG. Lipids and calcium uptake of sperm in relation to cold shock and preservation: a review. Reprod Fertil Dev 1993; 5:639-58.

11. Slaweta R, Wasowicz W, Laskowska T. Selenium content, glutathione peroxidase activity and lipid peroxide level in fresh bull semen and its relationship to motility of spermatozoa after freezing and thawing. Zentralb Veterinarmed A 1988; 35:455-60.

12. Srizaki I, Mohanakumar KP, Rauhala P, Kim HG, Yeh KJ, Chiueh CC. Manganese: a transition metal protects nigrostriatal neurons from oxidative stress in the iron-induced animal model of Parkinsonism. Neurosci 1998; 85:1101-11. 
13. Anand RK, Kanwar U. Role of some traces metal ions in placental membrane lipid peroxidation. Biol Tace Elem Res 2001; 82:61-75.

14. Chen MT, Cheng GW, Lin CC, Chen BH, Huang YL. Effects of acute manganese chloride exposure on lipid peroxidation and alteration of trace metal in rat brain. Biol Trace Elem Res 2006; 110:163-78.

15. Epperly MW, Epperly LD, Min Y, Wang H, Zhang X, Franicola D, et al. Overexpression of the MnSOD transgene product protects cryopreserved bone marrow hematopoietic progenitor cells from ionizing radiation. Radiant Res 2007; 168:560-6.

16. Saba H, Ines BH, Shambar M, Tanecia M, Cheryl L, Judit M, et al. Manganese porphyrin reduces renal injury and mitochondrial damage during ischemia/reperfusion. Free Radic Bio Med 2007; 42:1571-8.

17. de Leeuw FE, de Leeuw AM, DenDass JH, Colenbrander B, Verkleij AJ. Effects of various cryoprotective agents and membranestabilizing compounds on bull sperm membrane integrity after cooling and freezing. Cryobiol 1993; 3:32-44.

18. Campanella L, Gatta T, Ravera O. Relationship between anti-oxidant capacity and mangaese accumulation in the soft tissues of two fresh water mollusks: Unio pictorum mancus (Lamellibranchia, Urionidae) and viviparus ater (Gastropoda, Prosobranchia). J Limnol 2005; 64:153-8

19. Reddi AR, Jensen LT, Naranuntarat A, Rosenfeld L, Leung E, Shah R, et al. The overlapping roles of manganese and $\mathrm{Cu} / \mathrm{Zn} \mathrm{SOD}$ in oxidative stress protection. Free Radic Biol Med 2009; 46:154-62.

20. Adejuwon CA, Ilesanmi AO, Ode EO, Akinlade KS. Biophysical and biochemical analysis of semen in infertile Nigerian males. Afr J Med Sci 1996; 25:217-9.

21. Elbetieha A, Bataineh H, Darmani H, Al-Hamood MH. Effects of long term exposure to manganese chloride on fertility of male and female mice. Toxicol letters 2001, 119:193-201.

22. Coassin M, Ursini F, Bindoli A. Antioxidant effect of manganese. Arch Biochem Biophys 1992; 299:330-3.

23. Check ML, Check JH. Poor hypoosmotic swelling test results from cryopreserved sperm despite preservation of sperm motility. Arch Androl 1991; 26:37-41.

24. Lapointe S, Ahmad I, Bhur MM, Sirard MA. Modulation of post-thaw motility, survival, calcium uptake and fertility of bovine sperm by magnesium and manganese. J Dairy Sci 1996; 79:2163-9.

25. Bailey JL, Robertson L, Buhr MM. Calcium regulation, computerized motility parameters and the fertility of bovine spermatozoa. Can. J Anim Sci 1994; 74:53-8.

26. Cornell MO, McClure N, Lewis SEM. The effect of cryopreservation on sperm morphology, motility and mitochondrial function. Hum Reprod 2002; 17:704-9.

27. Shanon P, Curron B. Toxic effect and action of dead sperm on dilute bovine semen. J Dairy Sci 1972; 55:614-20.

28. Magnus O, Brekke I, Abyholm T, Purvis K. Effect of manganese and other divalent cations on progressive motility of human sperm. Arch Androl 1990; 24:159-66.

29. Singh P, Chand D, Georgie GC. Effect of vitamin E on lipid peroxidation in buffalo Bubalus bubalis L. Ind J Exp Biol 1989; 27:14-6.

30. Bilaspuri GS, Bansal AK. $\mathrm{Mn}^{2+}$ : A potent antioxidant and stimulator of sperm capacitation and acrosome reaction in crossbred cattle bulls. Arch Anim Breed 2008; 51:149-58.

31. Aggarwal A, Allamaneni S, Nallella K, George A, Mascha E. Correlation of reactive oxygen species levels with the fertilization rate after in vivo fertilization rate after in vitro fertilization: a qualified meta-analysis. Fertil Steril 2005; 84:228-31.

32. de Lamirande E, Gagnon C. A positive role for the superoxide anion in triggering hyperactivation and capacitation of human spermatozoa. Int J Androl 1993; 16:21-5.

33. Upreti GC, Jensen K, Munday R, Dugan Zich DM, Vishwanath R, Smith JF. Studies on aromatic amino acid oxidase activity in ram spermatozoa: Role of pyruvate as an antioxidant. Anim Reprod Sci 1998; 51:275-87.

34. Trinchero GD, Affranchino MA, Schang LM, Beconi MT. Antioxidant effect of bovine spermatozoa on lipid peroxidation. Comp Biol 1990; 8:339-50.

35. Beconi MT, Affranchino MA, Schang LM, Beorlegui NB. Influence of antioxidants on SOD activity in bovine sperm. Biochem Int 1991; 23:545-53.

36. Beconi MT, Francia CR, Mora NG, Affranchino MA. Effect of natural antioxidants on frozen bovine semen preservation. Theriogenol 1993; 40:841-51.

37. Mann T, Mann CL. Male reproductive function and semen. Springer-Verlag, New York $1981 ; 195-268$.

38. Marti E, Marti JI, Muino Balanco T, Cebrain-Perez JA. Effect of the cryopreservation process on the activity and immunolocalization of antioxidant enzymes in ram spermatozoa m. J Androl 2008; 1:25.

39. Marti E, Mara L, Marti J, Muino Blanco T, Cebrian-Perej J. Seasonal variations in antioxidant enzyme activity in ram seminal plasma. Theriogenol 2007; 67:1446-54.

40. Bilodeau JF, Chatterjee S, Sirard MA, Gagnon C. Level of antioxidants defenses are decreased in bovine spermatozoa after a cycle of freezing and thawing. Mol Reprod Dev 2000; 55:282-8

41. Jeyendran R, Vanderven, Znebeld L. The hypo-osmotic swelling test an update. Arch Androl 1992; 29:115-6.

42. Buege JA, Steven AD. In: Colowick SP, Kaplan NO, (Eds.,) Methods in Enzymology 52 (Biomembranes: Part C: Biological oxidants; Fleischers, Pecker L, Eds.,) Academic Press, New York 1978; 302-10.

43. Lowry RR, Tanslay TJ. Rapid colorimetric determination of free fatty acids. J Am Oil Chem Soc 1976; 53:470-2. 


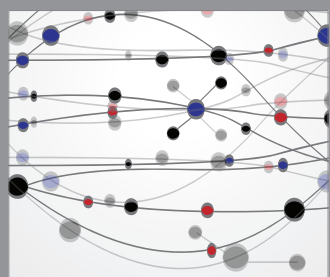

The Scientific World Journal
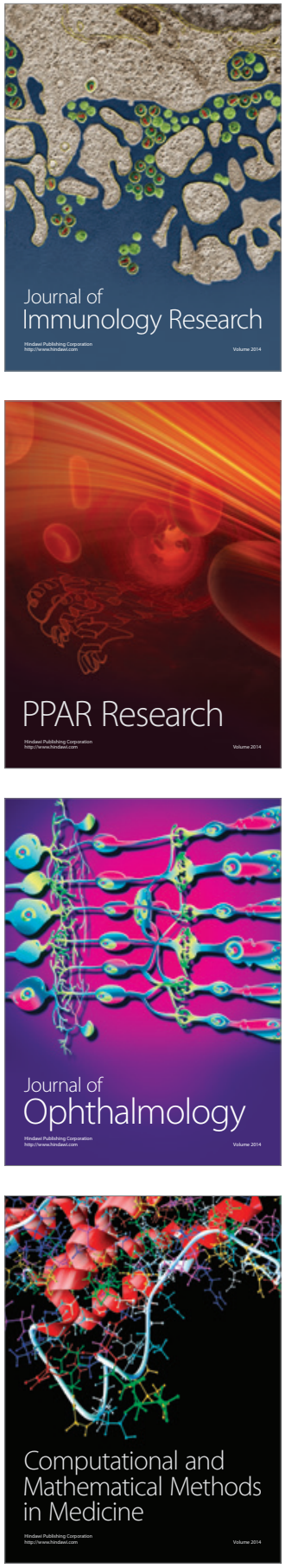

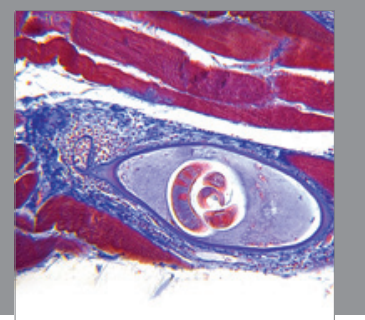

Gastroenterology

Research and Practice
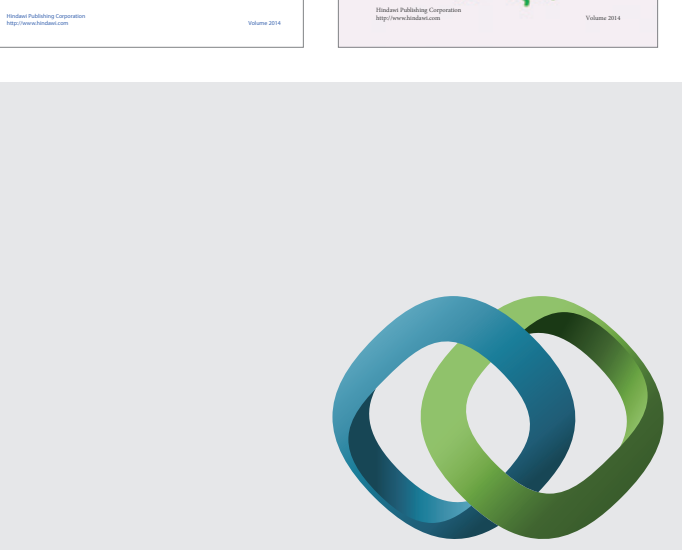

\section{Hindawi}

Submit your manuscripts at

http://www.hindawi.com
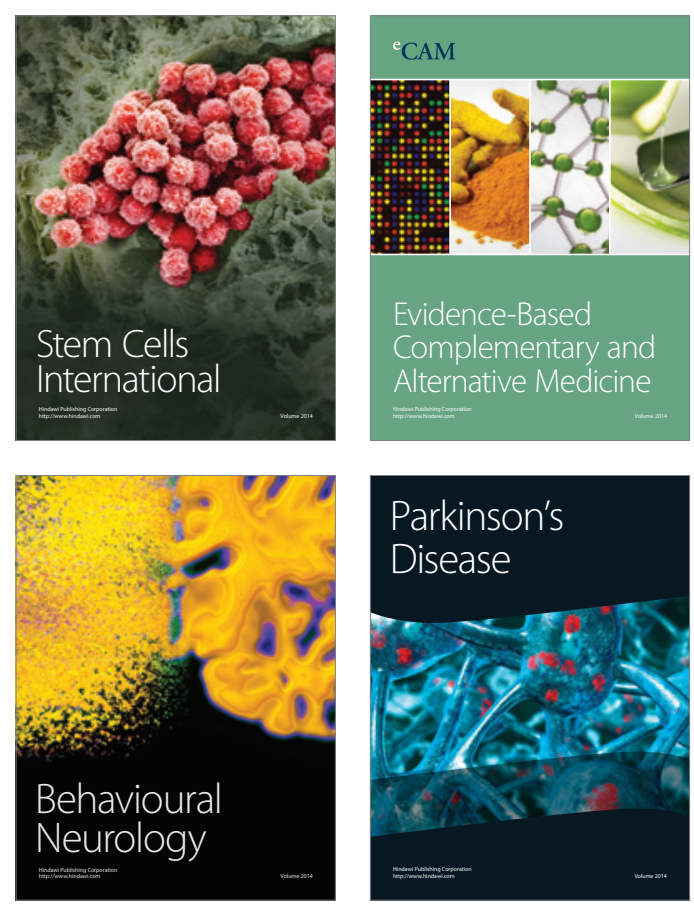

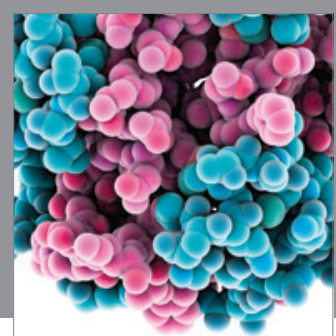

Journal of
Diabetes Research

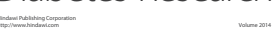

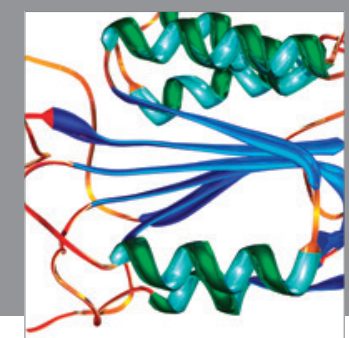

Disease Markers
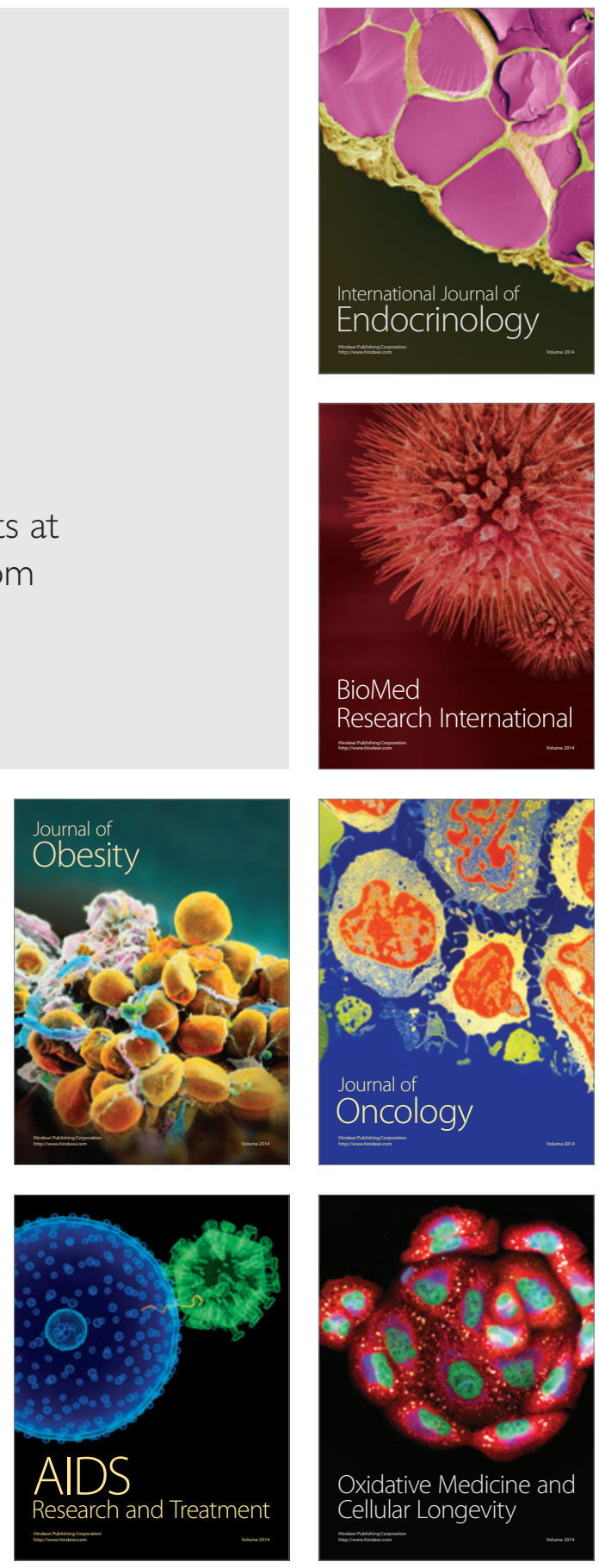